\title{
Mineralogy and facies variations of Devonian and Carboniferous shales in the Ukrainian Dniepr-Donets Basin
}

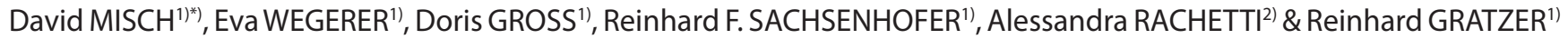 \\ 1) Department of Applied Geosciences and Geophysics, Montanuniversitaet Leoben, Peter-Tunner-Straße 5, 8700 Leoben, Austria; \\ 2) Department of General, Analytical and Physical Chemistry, Montanuniversitaet Leoben, Franz-Josef-Straße 18, 8700 Leoben, Austria; \\ $\left.{ }^{*}\right)$ Corresponding Author: David.Misch@unileoben.ac.at
}

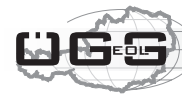

KEYWORDS Mudrocks; shales; facies; clay minerals; kaolinite; illite; Dniepr-Donets Basin

\begin{abstract}
The mineralogy of Devonian to Carboniferous shales from the Ukrainian Dniepr-Donets Basin (DDB) was investigated during this study. These shales show a high compositional variability in vertical and lateral directions. Furthermore, stratigraphic trends were found to be controlled both by climatic factors as well as by changing detrital input from the hinterland. High kaolinite contents and predominance of kaolinite over illite in the Tournaisian and partly in the lower Visean units are likely a result of intense chemical weathering related to the Hangenberg climatic event at the Devonian/ Tournaisian boundary. In contrast, abnormally high kaolinite contents in upper Visean and Serpukhovian samples at the basin center might be caused by different transport properties of kaolinite and illite, leading to selective concentration of small detrital kaolinite particles, which are often in the sub-micrometer range according to scanning electron microscopy observations. K/Al elemental ratios correlate well with illite/kaolinite ratios for samples in which significant amounts of both clay minerals are present, which enables a pre-evaluation of the relative kaolinite content based on bulk geochemical data. As kaolinite is suggested to decrease the fraccability of shales and to have a great influence on their wetting behaviour, this is useful information for explorational purposes. Higher feldspar contents in Devonian and Tournaisian samples, especially along the NE basin margin and in the shallow NW part of the DDB, are likely related to increased detrital input from magmatic precursors (e.g. in the Voronezh Massif) during (and shortly after) the active rift stage of the DDB. In general, feldspar contents are higher in proximal positions compared to the basin center, which is likely a result of shorter transport distances of the comparably large feldspar grains. Finally, the presence of expandable clay minerals down to depths of $6 \mathrm{~km}$ and the fact that no thermal maturity trend is visible down to these depths, proves, that a low post-depositional heat flow was present in the DDB. This is in good agreement with vitrinite reflectance measurements and thermal modelling results from previous studies, which suggest a low Mesozoic heat flow.
\end{abstract}

\section{Introduction}

The Dniepr-Donets Basin (DDB) is a Late Devonian riftbasin and extends over more than $600 \mathrm{~km}$ in central parts of the Ukraine (Fig. 1). It represents an important hydrocarbon province in Eastern Europe. Several organic-rich horizons within the Carboniferous succession in the DDB are considered potential hydrocarbon source rocks (Sachsenhofer et al., 2010; Misch et al., 2015), with the Serpukhovian and the Visean intervals likely being the most important ones (Sachsenhofer et al., 2010; Misch et al., 2015). Although only minor source potential was found for Devonian rocks in the northwestern and central DDB, they are probably the main hydrocarbon source in the Prypiat Trough to the northwest (Ulmishek et al., 1994). Misch et al. (2016a) investigated the shale oil/gas potential of the upper Visean succession within the northwestern and central DDB and showed bulk mineralogical data for more than 100 Visean mudrock samples from a specific horizon within the upper Visean (V-23;"Rudov Beds").

However, a comprehensive study on mineralogy, clay mineral distribution and facies changes throughout the Devonian and Carboniferous successions is lacking. Hence, this contribution uses vertically resolved $X$-ray diffractometry analyses (XRD) to determine systematic stratigraphic changes in mineralogy, as well as lateral variations within a specific stratigraphic interval. Furthermore, X-ray fluorescence (XRF) and scanning electron microscope (SEM) investigations were used to confirm XRD data. As unconventional hydrocarbon production strongly depends on the mineralogical composition, a more detailed understanding of lateral facies changes and the grade of variability within a certain stratigraphic interval will be of utmost importance for future exploration efforts. Finally, the relative importance of influencing factors such as paleoclimate and changing hinterland will be discussed.

\section{Geological setting}

The DDB is a Late Devonian rift-basin located within the East-European Craton (Fig. 1a,b), extending northwestwards into the Pripyat Trough and southeastwards into the Donbas Foldbelt (Kabyshev et al., 1998). The structure of the basin is characterized by depressions and elevated zones, including the Srebnen and Zhdanivske depressions in the northwestern DDB (Fig. 2a).

Middle Devonian pre-rift sediments represent the oldest strata in the DDB (Fig. 1c). The Upper Devonian syn-rift succession has a thickness of up to $4 \mathrm{~km}$ and 

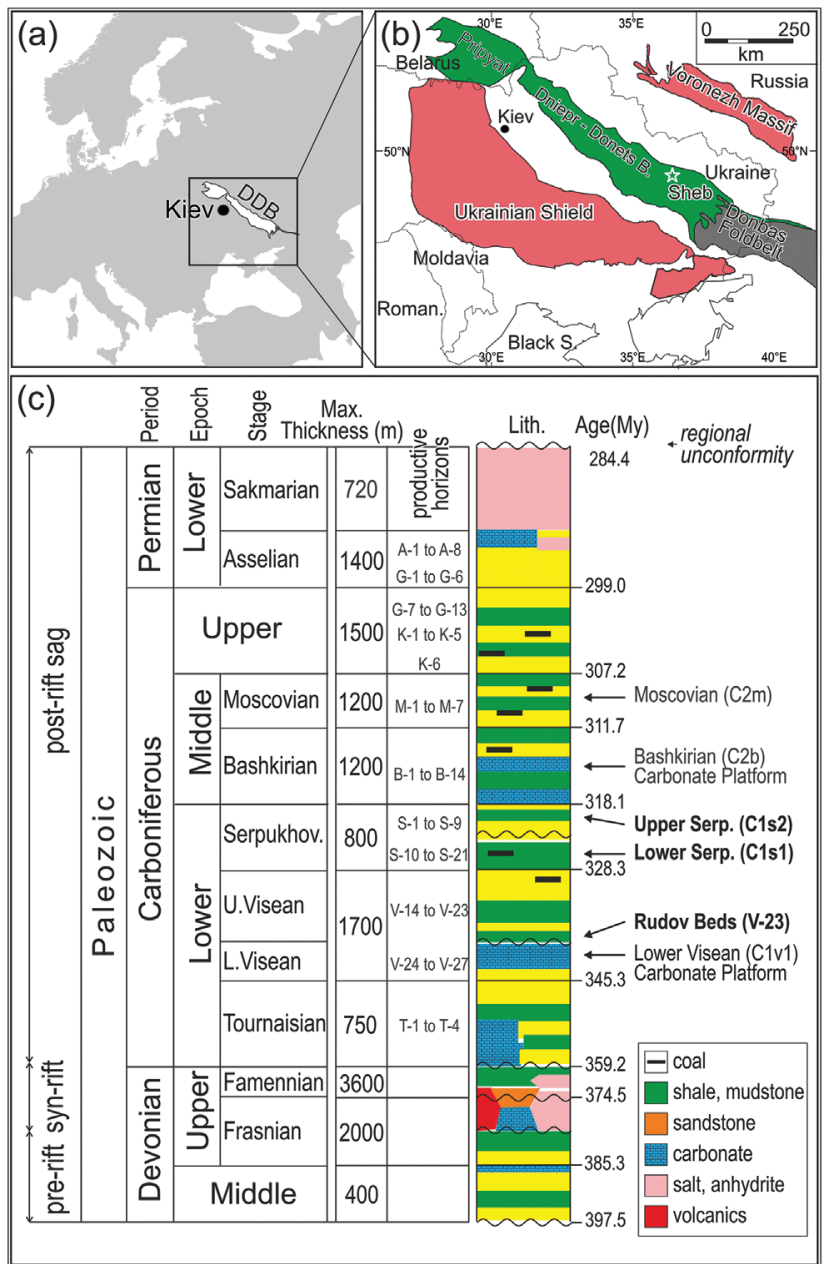

Figure 1: (a), (b) Regional setting of the Dniepr-Donets Basin (DDB) in Eastern Europe. (c) Chrono- and lithostratigraphy of the Paleozoic succession in the DDB (Sachsenhofer et al., 2010). Age data follow Gradstein et al. (2004). Information on "productive horizons" is shown according to Lukin in Ivanyuta et al. (1998).

includes clastic sediments, carbonate rocks, extensive salt (deformed to salt domes), and volcanic rocks (Kabyshev et al., 1998).

The Carboniferous post-rift succession, reaching thicknesses in excess of $10 \mathrm{~km}$, is characterized by cyclic deposition of siliciclastic and minor carbonate rocks in fluvial, lagoonal and shallow-marine environments. Water depth was less than $200 \mathrm{~m}$ except for the axial part of the basin. Typically each cycle, up to $50 \mathrm{~m}$ in thickness, includes a sand interval ("productive unit") and a shallow marine, organic-rich shale interval (Dvorjanin et al., 1996; see Fig. 1c). Four cycles are distinguished each in the Tournaisian (T-4 to $\mathrm{T}-1$ ) and lower Visean (V-27 to V-24) successions, which have a relatively low thickness and were deposited during a time with low tectonic activity. Continental facies prevailed in the northwestern part of the basin and along the basin margins and graded basinwards into marine environments. A major transgression from the southeast culminated in the establishment of a basin-wide lower Visean carbonate platform (Dvorjanin et al., 1996).

The more than $1000 \mathrm{~m}$ thick upper Visean succession includes 10 cycles ( $\mathrm{V}-23-\mathrm{V}$-14). The fine-grained part

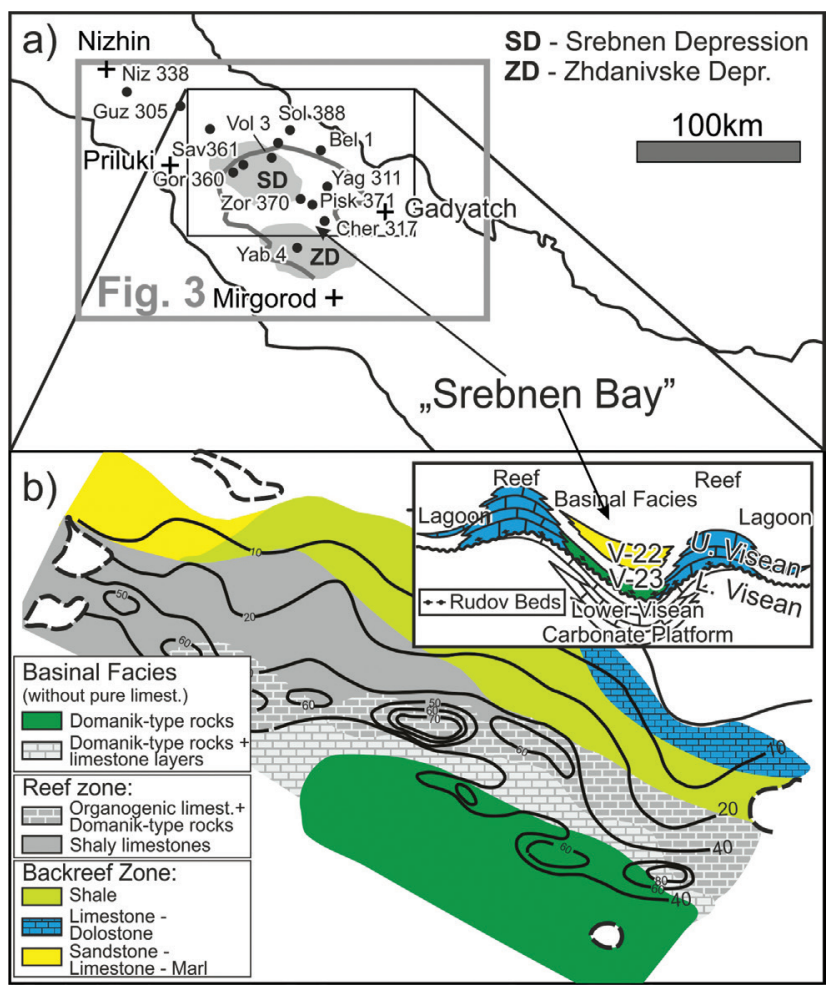

Figure 2: (a) Position of studied wells in relation to the Srebnen and Zhdanivske depressions in the northwestern DDB. The "Srebnen Bay" is a paleogeographic feature developed during Late Visean time. (b) Facies map of the "Srebnen Bay" (modified after Machulina \& Babko, 2004). Isopachs indicate thickness of upper Visean V-23 interval ("Rudov Beds"). The schematic cross-section (insert; after Babko et al., 2003) shows the syncline surrounded by a reef belt. "Rudov Beds" (V-23) are deposited in the central depression, overlying a lower Visean carbonate platform.

of the lowermost cycle V-23 is formed by the "Rudov Beds" and is up to $70 \mathrm{~m}$ thick (Figs. 1c; 2b). It is the most prominent black shale horizon in the DDB. Babko et al. (2003) and Machulina and Babko (2004) established facies zones in relation to the so-called Srebnen Bay, a vast syncline surrounded by a reef belt (Figs. 2a,b). They distinguished between a marginal clayey, a transitional clayey-calcareous, and a basinal siliceous Rudov facies. The lower part of the thick upper Visean section (V-22 to $\mathrm{V}-21$ ) is dominated by clay-rich shales. A general upward increase in sand content suggests an overall regressive trend (Dvorjanin et al., 1996).

Serpukhovian units (including 22 productive horizons) follow above an unconformity. The lower Serpukhovian succession is dominated by pelitic rocks. Lacustrine environments prevailed in the northwestern DDB, whereas marine environments existed in its southeastern part (Dvorjanin et al. 1996). Lower Serpukhovian coal formed along the southern basin margin and is extensively mined in the south(west)ern part of the Donbas Foldbelt (Sachsenhofer et al., 2003, 2012). The percentage of fluvial and deltaic sands increases in the upper Serpukhovian succession. Another hiatus separates Serpukhovian and Bashkirian units. A Bashkirian carbonate platform results from a major transgression from the southeast. Bashkirian and Moscovian coal seams are extensively mined in the Donbas Foldbelt, but extend also into the 
southeastern DDB. Clastic deposits, carbonate and evaporitic rocks prevail in the Permian section and are unconformably overlain by Mesozoic and Cenozoic rocks.

The DDB is an important hydrocarbon province with numerous oil fields prevailing in the northwestern part of the DDB as well as along the basin flanks, and gas fields (incl. the giant Shebelinka Field: $~ 500$ billion cubic meters; Ulmishek, 2001; Fig. 1b) dominating the deeper SE part of the basin. Multiple source rocks, including Tournaisian, Visean (e.g. Rudov Beds) and Serpukhovian black shales together with Serpukhovian and Moscovian coaly layers, contribute to the charging of traps in mainly Carboniferous and Permian clastic reservoir rocks (Ulmishek, 2001; Kabyshev et al., 1999; Misch et al., 2015).

\section{Samples and methods}

In total, 92 mudrock core samples were taken from twelve wells that drilled Devonian-Carboniferous intervals within the northwestern and central DDB. Due to restricted access to drill cores, no well resolved vertical profiles could be taken, but core samples of Serpukhovian (C1s), upper Visean (C1v2), lower Visean (C1v1), Tournaisian (C1t) and Devonian (D) age were obtained from multiple wells.

For the investigation of mineralogical compositions and clay mineral distributions, $\mathrm{X}$-ray diffraction (XRD) analyses were performed using a Panalytical diffractometer with a CuKa-radiation (1.54 Á, 45kV, $40 \mathrm{~mA})$. Measurement parameters were set at a goniometer speed rate of 0.5 ${ }^{\circ} 2 \theta /$ minute and a registration range from $2^{\circ}$ to $66^{\circ} 2 \theta$. For detailed investigation of the clay mineral fraction, textured mounts were measured four times at a goniometer speed rate of $0.5^{\circ} 2 \theta$ /minute with a registration range from $2^{\circ}$ to $42^{\circ} 2 \theta$ in the following order: (1) in untreated condition, (2) after solvation with ethylene glycol (EG; $\left.12 \mathrm{~h}, 60^{\circ} \mathrm{C}\right)$, after thermal treatment $(2 \mathrm{~h})$ at $(3) 350^{\circ} \mathrm{C}$ and $(4)$ at $550^{\circ} \mathrm{C}$. Qualitative analysis was done based on JCPDS (1974) and mineral quantification was performed following the method of Schultz (1964). The results were cross-checked using the ADM software (Version 6.22) of Wassermann Röntgenanalytik (Germany) which is based on the Rietveld method. To verify the quantitative analysis, a comparison between the percentage-composition based on XRD-data of the shale samples, XRD-data of quartz standards and calcite equivalent percentages from Rock Eval pyrolysis (data from Misch et al., 2016a) took place.

To confirm the obtained XRD data, element concentrations of the investigated samples were determined using a handheld X-ray fluorescence (XRF) instrument (Nitron $X L 3 t)$. The reliability of the handheld instrument has been tested during previous studies by comparison with data from a traditional calcination technique and a wavelength dispersive XRF spectrometer (Panalytical Axios; Sachsenhofer et al., 2015).

For SEM investigations, freshly broken surfaces of rock samples were coated with an Au layer to enhance conductivity. To prevent charging effects, relatively even surfaces were chosen for imaging. Investigations were conducted using a Zeiss Evo 50 SEM with a $\mathrm{LaB}_{6}$ filament, equipped with secondary electron (SE) and backscattered electron (BSE) detectors, as well as an energy-dispersive X-ray (EDX) detector for qualitative chemical analysis.

\section{Results}

\subsection{X-ray diffraction (XRD) and scanning electron microscopy (SEM)}

Varying amounts of quartz, plagioclase, potassium feldspar, calcite, siderite, expandable clay minerals $(E C M)$, mixed layer clay minerals (illite/smectite; $M L$ ), illite, kaolinite, chlorite and pyrite were detected in most samples. Trace amounts of apatite were found in some samples as well. The locations of sampled wells together with average quartz, feldspar, total carbonate and total clay mineral contents, as well as the number of investigated samples for each stratigraphic interval, are shown in Figure 3. In addition, average illite/kaolinite ratios are presented. Stratigraphic variations of the most important mineral phases are discussed in the following.

Bashkirian - Only two mudstone samples (wells Vol 314 , Yab 4) with a Bashkirian age are included in the present sample set. Hence, the lateral distribution of their mineral contents is not plotted in Figure 3. These largely carbonate-free samples contain significant amounts of quartz (22 and 38 wt.\%), feldspar (9 and 12 wt.\%) and clay minerals (51 and 65 wt.\%). Illite is more abundant than kaolinite in both samples.

Serpukhovian - 10 mudstone samples from 6 boreholes penetrating the Serpukhovian succession have been analyzed. Average quartz contents range between $23 \mathrm{wt} . \%$ and $71 \mathrm{wt} . \%$. With the exception of the sample from well Zor 370 and a slight enrichment in a sample from well Yag 311 in the eastern part of study area, the quartz content shows a relatively uniform distribution and no regional trends. Feldspar contents are very low in the western part of the study area (up to $3 \mathrm{wt} . \%$ ), but moderately high in its eastern part (e.g. $13 \mathrm{wt} . \%$ in Yag 311). With the exception of well Gor 360 (21 wt.\%), average carbonate percentages in the Serpukhovian are low (0-4 wt.\%). The total clay mineral percentage ranges between $25 \mathrm{wt} . \%$ in the quartz-rich sample from well Zor 370 , and 69 wt.\% in well Vol 3. The kaolinite/illite ratio ranges between 0.3 (Gor 360) and 4.8 (Zor 370).

Upper Visean - The upper Visean succession is represented by 44 samples from 11 boreholes, which are located within and outside the Srebnen Bay (see Fig. 3), an important paleogeographic feature during Late Visean time. Average quartz contents in the upper Visean range between 12 wt.\% in well Bel 1 (NE Srebnen Bay) and 37 wt.\% in wells Cher 317 and Yab 4 (SE Srebnen Bay; Zhdanivske Depression). Apart from well Bel 1, a remarkably low quartz content was found for well Zor 370 in the central Srebnen Bay (15 wt.\%). Average feldspar contents are generally low and range between $0 \mathrm{wt} . \%$ and $3 \mathrm{wt} . \%$, with the exception of wells Yab 4 (9 wt.\%) and Mosh 1 (8 wt.\%). Total carbonate percentages range between $0 \mathrm{wt} . \%$ and $21 \mathrm{wt} . \%$, with an 


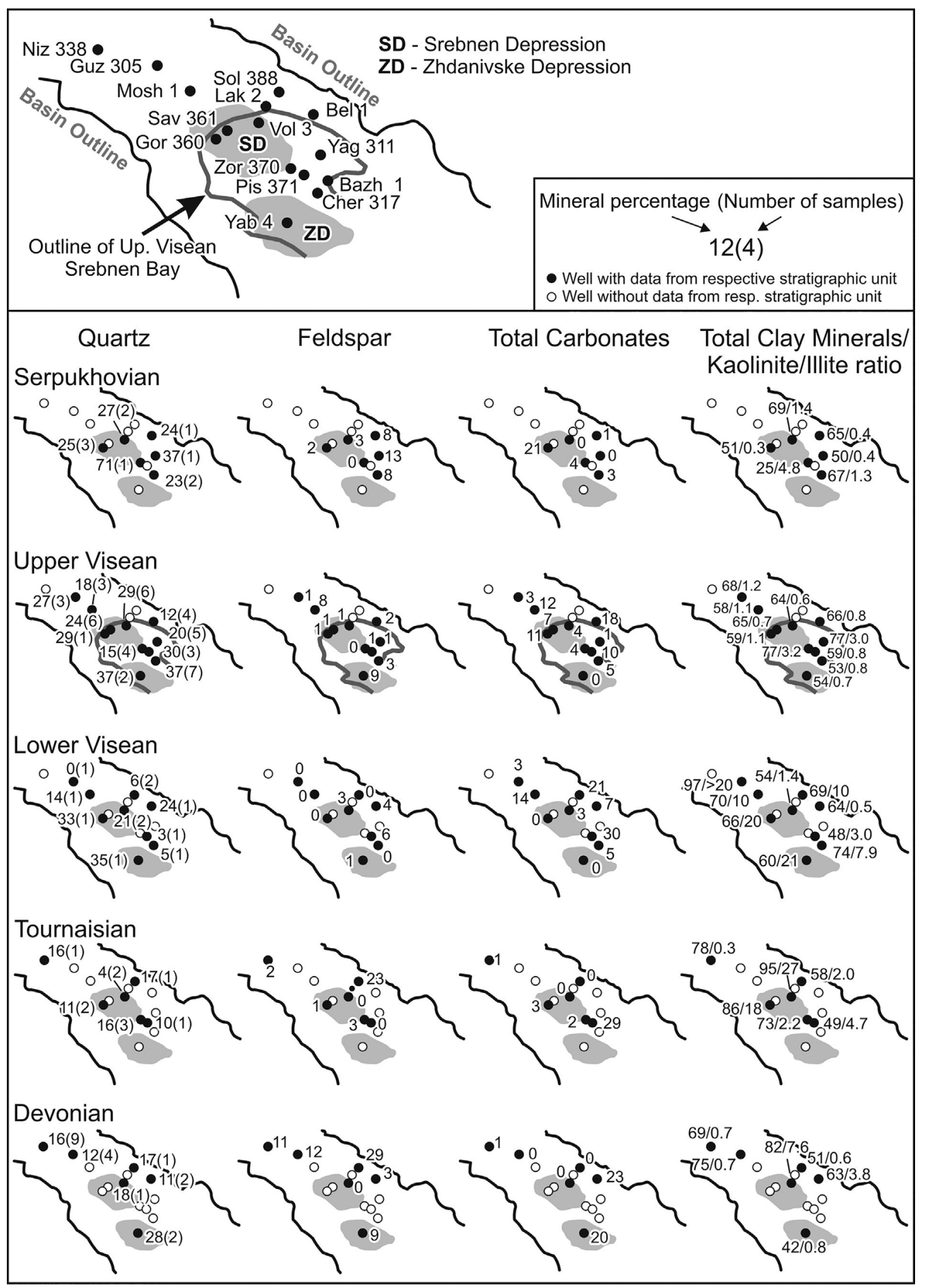

Figure 3: Summary of X-ray diffraction results for all investigated wells. Average quartz, cumulated feldspar, carbonate and clay mineral percentages as well as kaolinite/illite ratios are shown for the Serpukhovian, upper Visean, lower Visean, Tournaisian and Devonian units. Numbers in brackets indicate number of individual samples per stratigraphic unit.
Lower Visean - 11 samples from 9 boreholes show strongly varying average quartz contents (0-35 wt.\%) within the lower Visean succession. The highest values occur in the wells Gor 360 and Yab 4 located in the Srebnen and Zhadnivske depressions, respectively (see Fig. 3). Low contents were found for well Guz 305 (0 wt.\%), located NW of the Srebnen Depression, and wells Pis 371 and Cher 371 (3 wt.\% and 5 wt.\%, respectively), which are both located north of the Zhadnivske Depression. Feldspar contents within the lower Visean are generally low (0-6 wt.\%), with the highest amount occurring in the quartz-poor sample Pis 371. Average carbonate contents range between 0 wt. $\%$ and 30 wt. $\%$. The lowest percentages were found for quartz-rich samples from wells Gor 360 and Yab 4, whereas the sample from well Pis 371 hosts the highest amount of carbonates. Average clay mineral percentages within the lower Visean are relatively high and exceed 50 wt.\% in all wells except for well Pis 371 (48 wt.\%). A remarkably clay-rich sample was taken from well Guz 305 (97 wt.\%). With the exception of enrichment north of the Srebnen Bay (Sol 388, 21 wt.\%; Bel 1, 18 wt.\%). Total clay mineral percentages are generally high and exceed $50 \mathrm{wt} . \%$ in all investigated wells. The lowest percentages were found in the SE Srebnen Bay (Cher 317, 53 wt.\%; Yab 4, 54 wt.\%), whereas the highest values were found in the central well Zor 370 and the eastern well Yag 311 (77 wt.\% each). The average kaolinite/illite ratios of these wells are elevated (3.2 and 3.0, respectively), whereas they range between 0.7 and 1.2 for the remaining wells. well Bel 1, located northeast of the Srebnen Depression, kaolinite/illite ratios are $>1.0$ in all wells and significantly higher than in the upper Visean. Extraordinary high kaolinite/illite ratios ( 20) were found in the Srebnen and Zhdanivske depressions (Gor 360, Yab 4) and in the clay-rich sample from northwestern well Guz 305. According to SEM observations, the kaolinite shows grain sizes in the sub-micron range and is detrital in origin (randomly distributed rather than authigenic crystallites; Fig. 4a,b). 


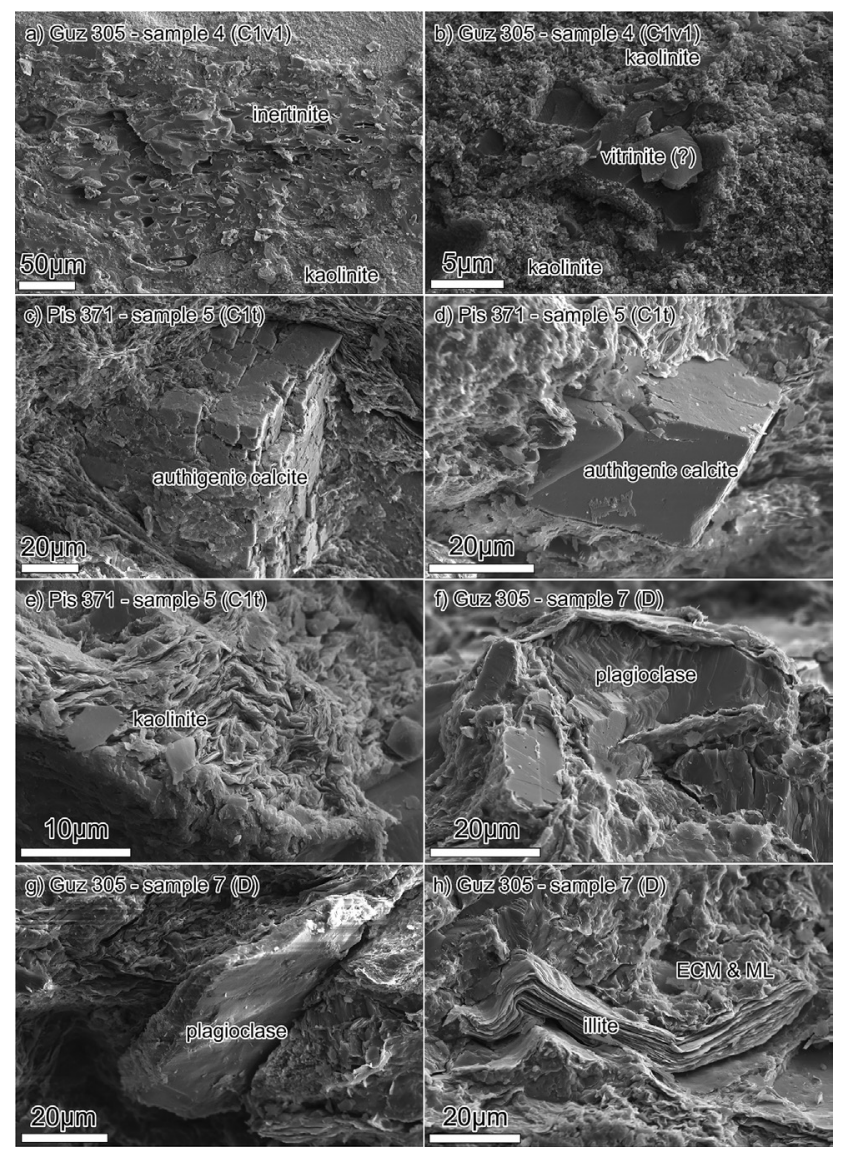

Figure 4: Scanning electron microscopy (secondary electron) images of selected shales from the DDB. (a, b) Sample Guz 305/4, lower Visean in age, is rich in terrestrial macerals such as inertinite and vitrinite ( 40 wt.\%TOC). The mineral matrix is dominated by fine-grained, detrital kaolinite, often showing grain sizes in the sub-micrometer range. $(c, d)$ authigenic calcite cement forming euhedral crystallites in the Tournaisian sample Pis $371 / 5$. (e) Platy detrital kaolinite dominates the clay mineral fraction in sample Pis $371 / 5$. (f, g) Relatively coarse plagioclase grains are abundant in the Devonian sample Guz 305/7. (h) The clay mineral fraction in sample Guz 305/7 is composed of coarser illite aggregates and a finely dispersed mixture of ECM and ML clay minerals.

Tournaisian - The Tournaisian succession (10 samples from 6 wells) is relatively quartz-poor (4-17 wt.\%). Similarly, average feldspar contents are low (0-3 wt.\%), with the exception of one feldspar-rich sample from well Sol 388 (23 wt.\%), located near the northeastern basin margin. This sample also hosts the highest amount of quartz (17 wt.\%). One sample from well Pis 371 is rich in carbonates (29 wt.\%), partly occurring as authigenic, euhedral calcite crystals according to SEM observations (Fig. 4c,d). All other samples do not host significant amounts of carbonate minerals (0-3 wt.\%). Similar to the lower Visean, Tournaisian samples are rich in clay minerals (49-95 wt.\%). The lowest cumulated amount of clay minerals was found for well Pis 371, whereas wells Gor 360 and Vol 3 located in the Srebnen Depression are the most clay-rich (86 wt.\% and 95 wt.\%, respectively). Very high kaolinite/illite ratios were found in Tournaisian samples from these wells (Vol 3: 27.3; Gor 360: 17.8). According to SEM images, kaolinite in well Pis 371 seems to be predominantly detrital in origin (Fig. 4e).
Devonian - The Devonian succession (19 samples from 6 wells) is relatively quartz-poor, with the exception of two samples from the Zhdanivske Depression (Yab 4: averaging at 28 wt.\% ). In contrast, average feldspar contents are occasionally elevated in comparison to the remaining stratigraphic intervals, with contents exceeding 10 wt.\% in NW wells Niz 338 and Guz 305 (SEM images in Fig. 4f,g), and the highest average feldspar content of all investigated samples in one sample from well Sol 388 ( $\mathrm{N}$ of the Srebnen Bay). The lowest feldspar contents were found for wells Vol 3 and Bel 1, whereas two samples from the southernmost well Yab 4 host considerable amounts ( 9 wt.\% on average). Wells Bel 1 and Yab 4 host high amounts of carbonate minerals (23 wt.\% and 20 wt.\%, respectively), while Devonian samples from all remaining wells do not show significant amounts of carbonates ( $\leq 1 \mathrm{wt} . \%)$. Total clay mineral percentages are generally high and exceed $50 \mathrm{wt} . \%$ in all wells except for Yab 4 in the Zhdanivske Depression (42 wt.\%). The highest percentage was found for one sample from well Vol 3 (82 wt.\%), and furthermore, high average percentages were also found for wells Niz 338 and Guz 305 in the NW DDB (69 wt.\% and 75 wt.\%, respectively; Fig. 4h). Except for the clay-rich sample from well Vol 3 (7.6) and two samples from well Bel 1 NE of the Srebnen Depression (3.8), the average kaolinite/illite ratios in the Devonian succession are $<1.0$ and hence mostly lower compared to the Tournaisian and lower Visean intervals.

\subsection{X-ray fluorescence (XRF)}

The most important elemental compositions from x-ray fluorescence spectroscopy are shown in Figure 5. A weak correlation was found for $\mathrm{Si}$ contents and quartz percentages obtained via XRD, whereas a good correlation was found for Ca contents and calcite percentages. The K/AI ratio correlates well with the ratio of illite/ kaolinite (see also Yarincik et al., 2000; Ross and Bustin, 2008), for illite/kaolinite ratios up to $\sim 3$. For samples with higher illite/kaolinite ratios (corresponding to samples with kaolinite contents below $10 \mathrm{wt} . \%$ ), the correlation is very poor. This is because of difficulties related to the determination of small amounts of kaolinite and because the K/AI ratio is obviously also controlled by other sources (e.g. feldspars). The ratio of $\mathrm{Zr} / \mathrm{K}$, plotted against quartz percentages, is often used as a parameter for average grain size (e.g. Sachsenhofer et al., 2015). In the investigated sample set, no correlation was found for the $\mathrm{Zr} / \mathrm{K}$ ratio (usually zircon is associated with coarser-grained sediments; Ross and Bustin, 2009) and the percentage of quartz. Furthermore, no correlation was found for the ratios $\mathrm{Si} / \mathrm{Al}$ and $\mathrm{Ti} / \mathrm{Al}$, both usually indicative for increased influx of coarser detritus as well (Calvert et al., 1996; Ross and Bustin, 2009). Instead, a weak positive correlation of $\mathrm{Ti}$ and $\mathrm{Al}$ (and the absence of a correlation between $\mathrm{Ti}$ and the percentage of quartz) suggests that Ti concentrations within the investigated sample set are at least partly sourced from 

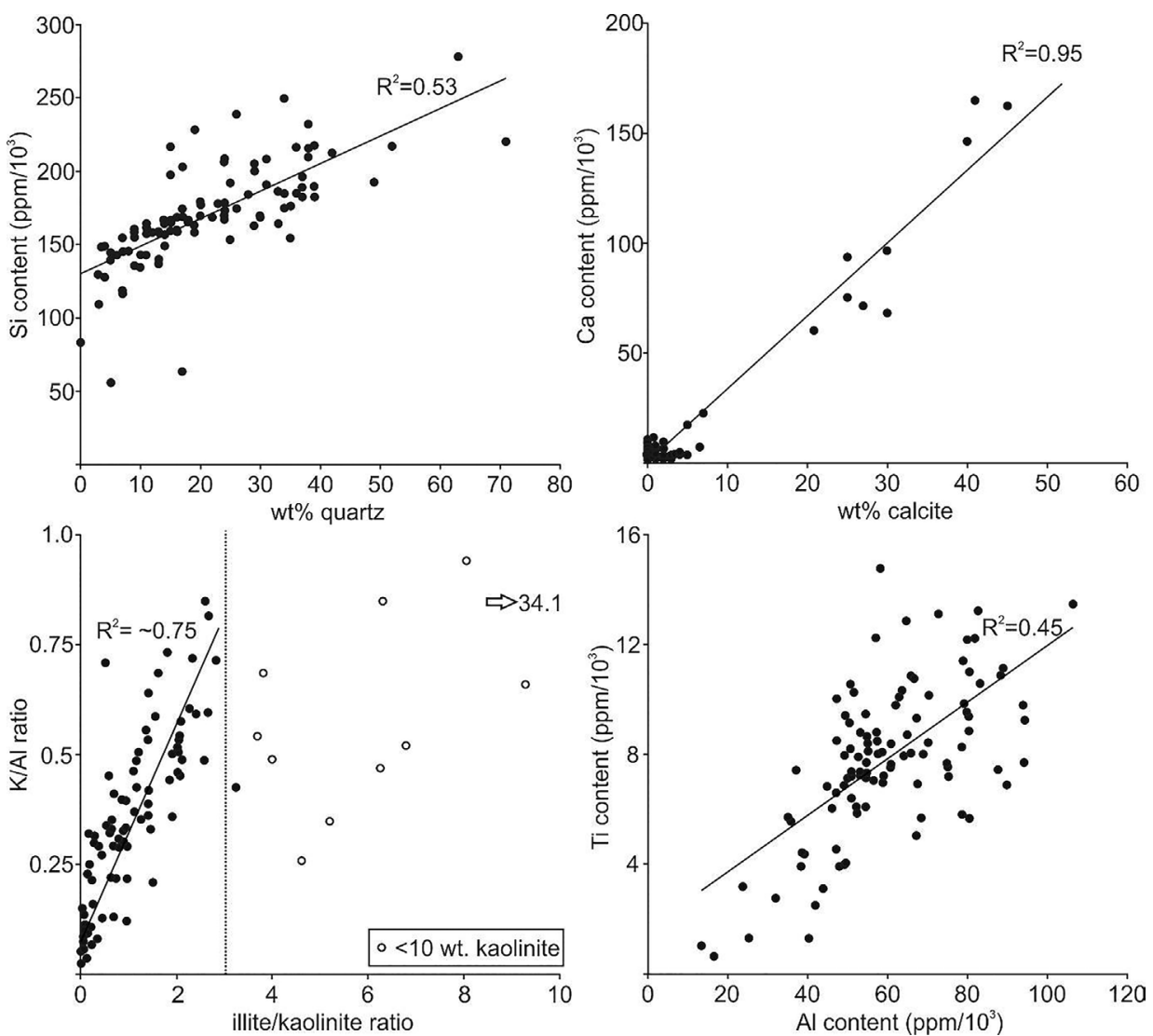

Figure 5: X-ray fluorescence correlations for the investigated sample set. Si and Ca concentrations correlate well with quartz and calcite percentages, respectively. The K/Al ratio correlates with the ratio of illite versus kaolinite in samples where both minerals are present in significant amounts and none of both minerals is extremely dominant compared to the other one (illite/kaolinite ratios up to $\sim 3$ ). Ti shows a weak correlation with $\mathrm{Al}$, indicating that at least part of the Ti concentration is contributed by clay minerals rather than heavy minerals which would indicate a higher input of coarse detritus.

clay minerals. No correlation was found between the $\mathrm{Ni}$ and $\mathrm{V}$ contents, as well as the $\mathrm{V} / \mathrm{Cr}$ ratio (parameters that are usually indicative for increasingly deficient oxygen levels during deposition; e.g. Jones and Manning, 1994) and the total organic carbon content. Instead, a weak correlation of total $\mathrm{Cr}$ and $\mathrm{V}$ contents suggests a similar (detrital?) source for both elements. V/Cr ratios are generally lower than reported by Ross and Bustin (2009) for Devonian to Mississippian black shales from the Western Canadian Sedimentary Basin, despite similar TOC contents.

\section{Discussion}

The present results indicate a strong lateral and vertical variability in the mineralogical composition of the investigated Devonian-Carboniferous mudrocks (Fig. 6). Box plots displayed in Figure 7 emphasize differences between stratigraphic units. The variability likely can be referred to (i) drastic climate changes and hence changing weathering conditions in the late Devonian and during Carboniferous times, (ii) the imprint from provenance in the hinterland as well as (iii) lateral facies variations in certain stratigraphic intervals (e.g. upper Visean "Rudov Beds"; Fig. 8). All three factors are discussed separately in the following.

\subsection{Climatic controls on shale mineralogy in the DDB}

Rapid global environmental changes in the Late Devonian led to major biotic crises at the Frasnian-Famennian (Kellwasser Event; Buggisch, 1991; Averbuch et al., 2005) and the Famennian-Tournaisian boundaries (Hangenberg Event; Bábek et al., 2016). Obviously, such drastic variations in paleoclimate also led to changing subaerial weathering conditions in the provenance area during Late Devonian/Early Carboniferous times, reflected by changes in clay mineralogy. Whereas moderate chemical weathering typically results in illite-rich composition of sediments, kaolinite is a product of intense weathering under humid conditions (Rachold and Brumsack, 2001; Niebuhr, 2005). Furthermore, the clay mineral distribution within a mudrock strongly influences the $\mathrm{K} / \mathrm{Al}$ ratio, with high ratios reflecting high illite contents, and dominance of smectite, chlorite or kaolinite resulting in low $\mathrm{K} / \mathrm{Al}$ ratios (Bábek et al., 2016). $\mathrm{K} / \mathrm{Al}$ ratios correlate well with illite/kaolinite ratios for samples that show an illite/kaolinite ratio up to 3 . For samples with ratios $>3$, the actual illite content is underestimated by K/Al. This is most likely due to the fact that additional $\mathrm{Al}$ and $\mathrm{K}$ sources (e.g. detrital mica, feldspars) lead to a certain bias and reduce the sensitivity of this parameter.

Within the investigated sample set, Tournaisian and some lower Visean samples show remarkably high average percentages of kaolinite (and hence K/Al ratios), likely reflecting climatic variations related to the Hangenberg Event, as reported by Bábek et al. (2016). In contrast, upper Visean and Serpukhovian intervals mostly show dominance of illite or equal proportions of kaolinite and illite (kaolinite/illite ratios close to or slightly below 1), although occasionally, single samples in the upper Visean host high amounts of kaolinite as well. In one basin-centered well, both upper Visean and Serpukhovian samples are remarkably kaolinite-rich, which is likely a result of remobilization of kaolinite from older stratigraphic units. However, the high abundance of kaolinite in the basin center could also reflect differences in transport behaviour of kaolinite and illite. 


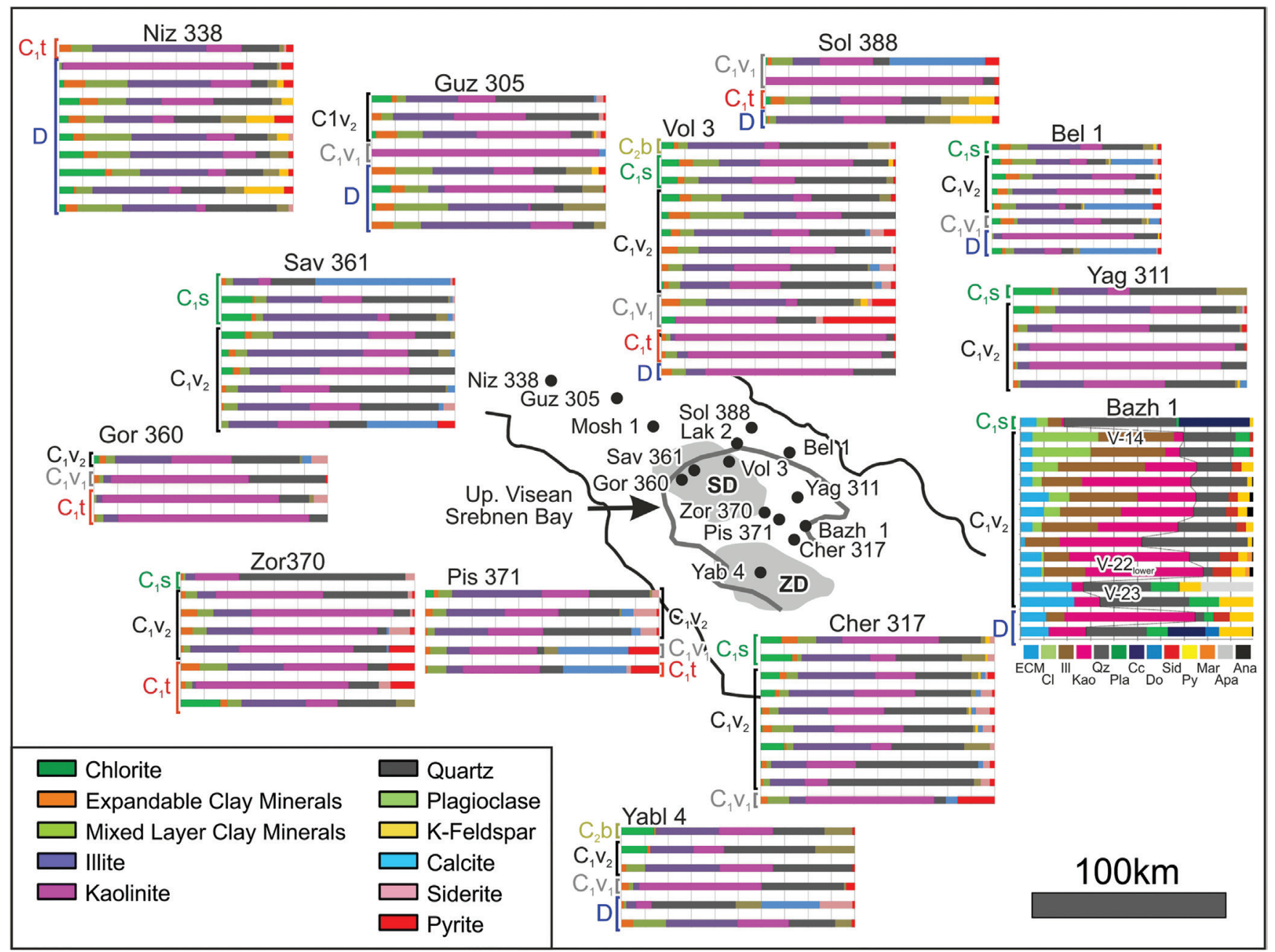

Figure 6: Schematic mineralogical profiles through the investigated wells. Results from well Bazh 1 (Misch et al., 2014) are shown for comparison. Great lateral and vertical variability, as well as some stratigraphic trends, are visible. The basin outline, as well as the position of the Srebnen and Zhdanviske depressions (SD, ZD) and the outline of the Srebnen Bay are shown.

Results from well Bazh 1 (Misch et al., 2014) are included in Figure 6. In this well, samples from 11 different Visean horizons show a clear upward decrease in kaolinite contents from c. 50 wt.\% (V-22 $2_{\text {lower }}$ ) to < $5 \mathrm{wt} . \%(\mathrm{~V}-14)$, supporting the change in clay mineral composition over time.

\section{$\mathbf{5 . 2}$ Influence of varying provenance conditions}

Relatively high feldspar contents were determined for Devonian and Serpukhovian samples especially along the NE basin margin and in the shallow NW part of the DDB. A single Tournaisian samples from this part is also rich in feldspar. According to SEM observations, feldspar (dominantly plagioclase) is at least partly detrital in origin, although in some upper Visean samples from the Srebnen Bay, diagenetic albite exists as well (Misch et al., subm.). Increased input of detrital feldspar during (and shortly after) the active rifting phase seems a likely assumption, as physical weathering might have been intense during these times and a relatively short transport distance and high relief enabled the concentration of relatively coarse detritus in the initial stage of basin infill. Possible precursors are feldspar-rich magmatites from the surrounding magmatic complexes, e.g. Archaean to Paleoproterozoic granitoids in the Voronezh Massif, which confines the DDB to the N and NW (Fig. 1b; Shchipansky and Bogdanov, 1996). In the post-rift succession (lower Visean-Serpukhovian), feldspar contents are partly higher in distal positions compared to the basin center (with the exception of certain samples rich in diagenetic (?) albite). This might be a result of selective transport, which leads to a relative enrichment of fine detritus (e.g. kaolinite) in the central part of the basin, whereas coarser detrital grains are more abundant at the basin rims. In contrast, quartz contents within the investigated sample set are almost randomly distributed throughout the basin, and Machulina and Babko (2004) and others reported a quartz-rich siliceous basinal facies (in contrast to feldspar enrichment at distal positions) for the upper Visean unit. This is likely due to the fact that quartz is only partly present as relatively coarse detrital grains, whereas microcrystalline quartz originates from biogenic silica, which is contributed by deep water radiolaria. Their abundance is largely restricted to basinal settings (see also Misch et al., 2016b). 


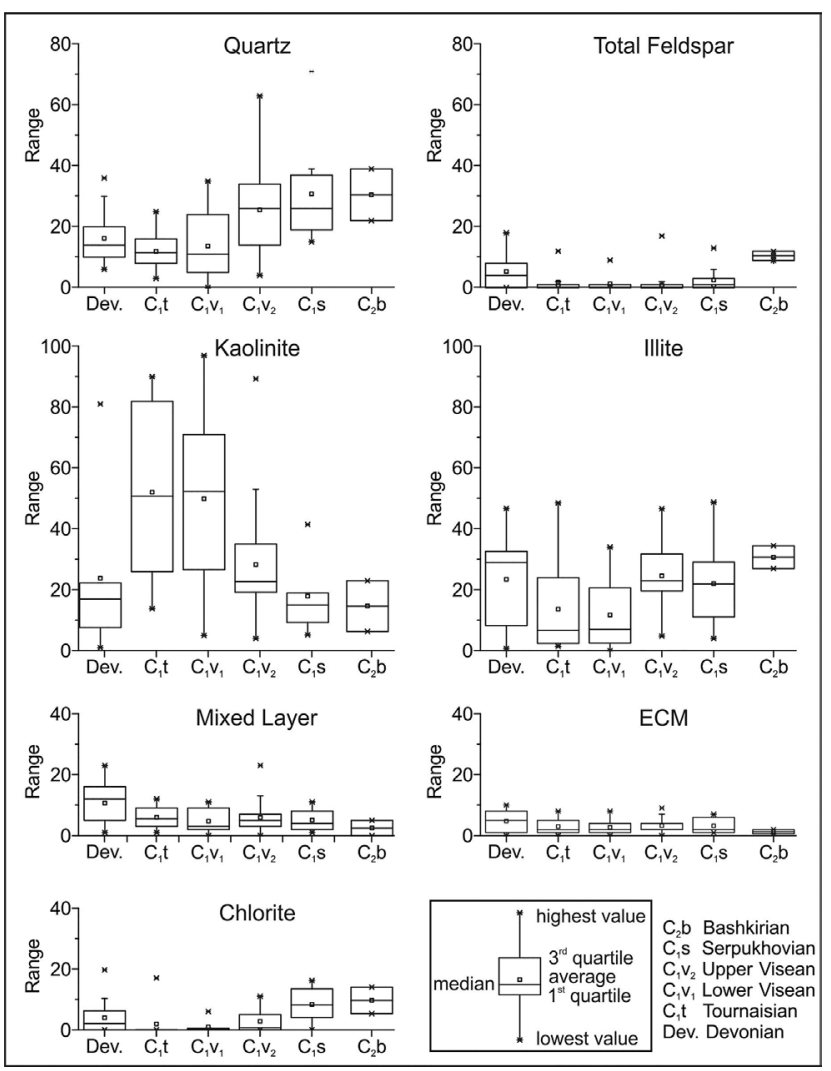

Figure 7: Box and whisker-plots (after Tukey, 1977) of mineral distributions for each investigated stratigraphic unit.

\subsection{Influence of facies variations within the Rudov Beds (V-23)}

Deposition of the organic matter-rich Rudov Beds (V23) was assisted by a peculiar paleogeographic setting within a basinal area (Srebnen Bay) that was surrounded by a reef zone (see Fig. 2b). Machulina and Babko (2004) distinguished between a marginal clayey, a transitional clayey-calcareous and a basinal siliceous Rudov facies. Misch et al. (2016a) studied the bulk mineralogy of a high number of samples representing different positions within the Srebnen Bay. Their data reveal that bulk mineralogy is extremely variable even within each facies zone and also in vertical direction throughout the V-23 horizon. Partly this is also due to authigenic carbonate phases and other diagenetic precipitates within the sediment (Fig. 8a, b).

\subsection{Implications for paleo heat flow}

Previous thermal modelling studies in the DDB yielded the best results when assuming a low Mesozoic heat flow (Shymanovskyy et al., 2004; Misch et al., 2016a; Mohsenian, 2013). This is indicated by a moderate vitrinite reflectance gradient down to depths of $>5000$ $\mathrm{m}$, as well as biomarker data obtained from source rock extracts and associated oils (e.g. hopane/sterane isomerization; Misch et al., 2015; 2016a). Furthermore, Misch et al. (2016a) found ECM to be present in trace amounts
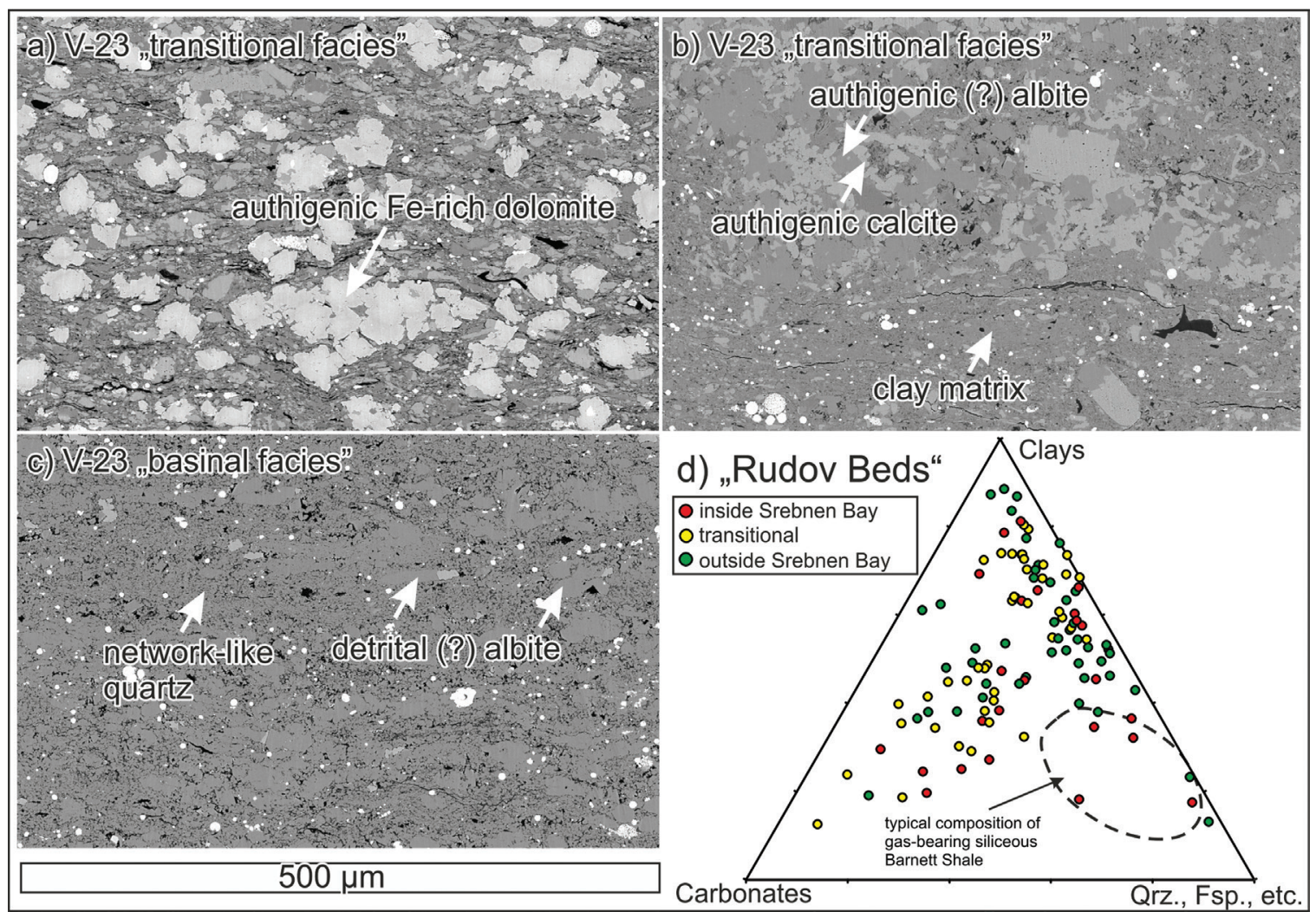

Figure 8: $(a, b)$ BSE images showing strong authigenic carbonate cementation in two samples from the transitional facies of the upper Visean V-23 interval ("Rudov Beds"). (c) BSE image of a sample from the basinal facies, hosting network-like quartz and considerable amounts of albite (SEM images partly from Misch et al., subm.). (d) Mineralogy of Rudov Beds (V-23) from X-ray diffractometry (after Misch et al., 2016a). The composition of gas-bearing, siliceous Barnett Shale is shown for comparison (after Jarvie et al., 2007). 
in upper Visean shales from depths up to $5 \mathrm{~km}$. Obviously, the low maturity gradient diminishes the potential for unconventional hydrocarbon production from organic matter-rich mudrocks. Results of this study confirm these findings, showing that ECM and illite/smectite mixed layer clay minerals $(\mathrm{ML})$ are present down to depths of $6 \mathrm{~km}$, and that no maturity trend in the presence of both ECM and ML exists (Fig. 9). Nevertheless, Misch et al. (2014) found an increased ordering („Reichweite") of ML in several Visean and Devonian samples from depths $>5 \mathrm{~km}$, a parameter that was not studied in detail during this study.

\subsection{Implications for unconventional hydrocarbon production}

Misch et al. (2015) identified the upper Visean and Serpukhovian units as the most important hydrocarbon source rocks in the NW DDB, but also found limited source potential for Tournaisian and Devonian mudrocks. Jarvie et al. (2007) and others introduced certain quality parameters for proven and successful shale gas/oil plays, which are generally used for the evaluation of new unconventional targets. Using these (and other) established quality parameters, Misch et al. (2016a) investigated the shale oil/gas potential of the upper Visean succession in the NW DDB (see above) and found an unfavourable mineralogical composition as one of the main economic risk factors. Findings of the current study confirm, that Devonian-Carboniferous mudrocks in the NW and central DDB are often too rich in clay minerals, and are mostly lacking the desired quartz content of $>30 \mathrm{wt}$ \% (Jarvie et al., 2007; Fig. 10). Tournaisian and lower Visean units are especially clay mineral-rich and quartz-poor (Figs. 7, 10), and furthermore host high amounts of kaolinite,

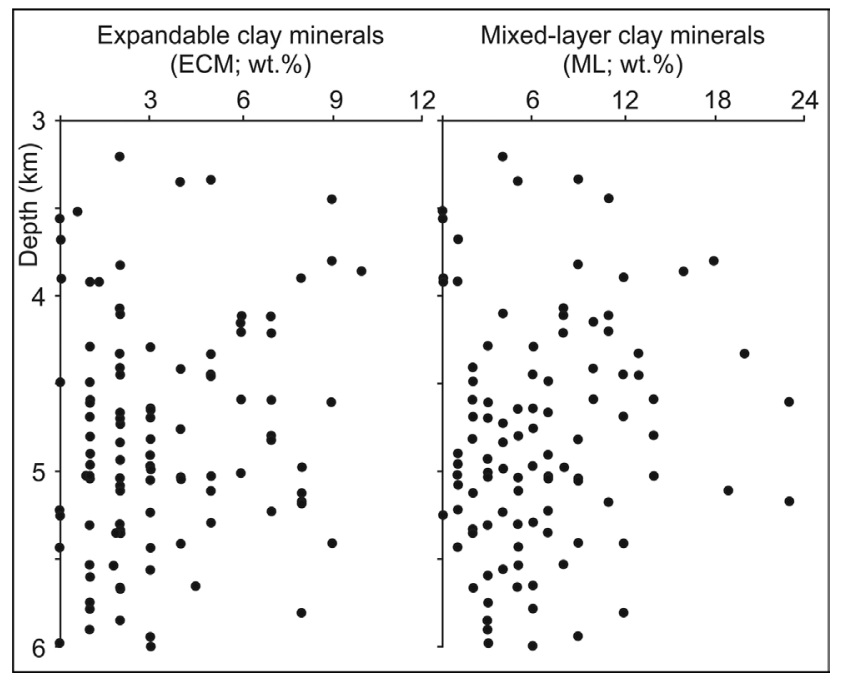

Figure 9: Depth profiles of expandable and mixed layer (illite/smectite) clay mineral percentages. No decreasing depth trend is visible, which indicates comparably low thermal stress down to depths of $6 \mathrm{~km}$. These data agree with findings from Misch et al. (2016a) and confirm previous thermal modelling results (e.g. Shymanovskyy et al., 2004; Mohsenian, 2013; Misch et al., 2015).

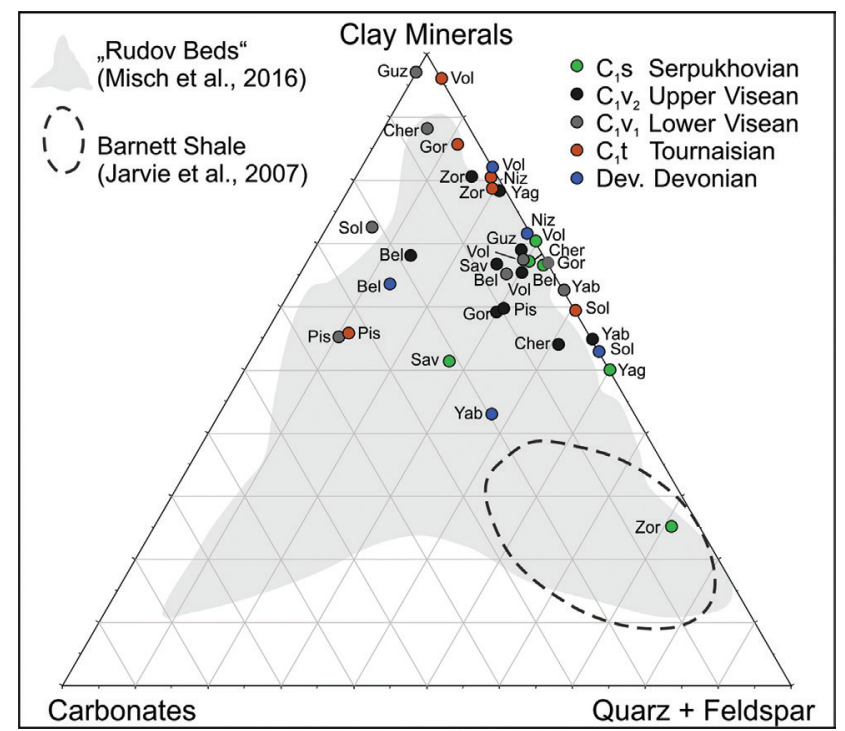

Figure 10: Ternary plot showing the fractions of quartz+feldspar, carbonates and total clay minerals. The compositional variability of upper Visean samples investigated by Misch et al. (2016a), as well as the typical composition of Barnett Shale (after Jarvie et al., 2007), are shown for comparison.

suggested to decrease the "fraccability" of shales (Misch et al., 2016a). High kaolinite contents were partly also found in the upper Visean, although the average quartz content is slightly higher compared to the underlying units. Quartz contents in the Serpukhovian are comparable to the upper Visean, but the average kaolinite content is considerably lower (Fig. 7), which might be favourable for fracturing behaviour.

Finally, during this study it could be proven that a handheld XRF device enables a quick pre-evaluation of kaolinite (based on $\mathrm{K} / \mathrm{Al}$ ), calcite (based on $\mathrm{Ca}$ ) and quartz (based on Si) percentages, which is useful in order to assess the most critical mineral phases for unconventional hydrocarbon production.

\section{Conclusions}

This study revealed that the mineralogical composition of Devonian-Carboniferous shales from the Ukrainian DDB varies strongly in lateral and vertical directions. These variations are controlled both by climatic factors as well as changing detrital input from the hinterland. High kaolinite contents and predominance of kaolinite over illite in the Tournaisian and partly in the lower Visean units can likely be referred to intense chemical weathering in the course of the Hangenberg Event at the Devonian/Tournaisian boundary. In contrast, abnormally high kaolinite contents in upper Visean and Serpukhovian samples from one well at the basin center might be a result of different transport properties of kaolinite and illite, leading to selective concentration of small detrital kaolinite particles, which are often in the sub-micrometer range according to SEM observations. $\mathrm{K} / \mathrm{Al}$ ratios obtained with a handheld XRF device correlate well with illite/kaolinite ratios at least for samples 
in which significant amounts of both clay minerals are present, which enables a pre-evaluation of the relative kaolinite content based on this method. As kaolinite is suggested to decrease the fraccability of shales and to have a great influence on their wetting behaviour, this might be useful for explorational purposes. In a similar way, Ca contents from handheld XRF are viable for the estimation of calcite percentages, and Si contents in general reflect quartz percentages, despite other $\mathrm{Si}$ sources within the sediment.

Higher feldspar contents in Devonian and Tournaisian samples, especially along the NE basin margin and in the shallow NW part of the DDB, are likely related to increased detrital input from magmatic precursors (e.g. in the Voronezh Massif) during (and shortly after) the active rift stage of the DDB. In general, feldspar contents are higher in proximal positions compared to the basin center, which is likely a result of shorter transport distances of the comparably large feldspar grains. However, it is important to note that during previous studies, authigenic albite was also detected in upper Visean samples from the DDB.

The presence of ECM down to depths of $6 \mathrm{~km}$, and the fact that no thermal maturity trend is visible down to these depths, proves that a low post-depositional heat flow was present in the DDB. This is in good agreement with vitrinite reflectance measurements and thermal modelling results from previous studies, which suggest a low heat flow during the Mesozoic.

\section{Acknowledgments}

The authors would like to thank the staff members of the Ukrainian State Geological Institute (V. Makogon, T. Prigarina) and Shell Ukraine E\&P for providing core samples from the DDB. Gerhard Hawranek (Chair of Physical Metallurgy, Montanuniversität Leoben) and Jop Klaver (Microstructure and Pores $\mathrm{GmbH}$, Aachen) are thanked for help with the acquisition of SEM images. The first author is grateful to Prof. Janos L. Urai for facilitating a guest stay at RWTH Aachen University, during which this paper was composed. Useful comments of Gabor Tari and Franz Ottner helped to improve the initial manuscript. This work was funded by the Austrian Science Fund FWF (grant no. P 29310-N29).

\section{References}

Averbuch, O., Tribovillard, N., Devleeschouwer, X., Riquier, L., Mistiaen, B. and Van Vliet-Lanoe, B., 2005. Mountain building-enhanced continental weathering and organic carbon burial as major causes for climatic cooling at the Frasnian-Famennian boundary (c. $376 \mathrm{Ma})$ ? Terra Nova, 17, 25-34.

Babko, I.M., Gontcharov, V.E. and Kononenko, L.P., 2003. Modern view on carbonate deposits near the base of the Visean stage in the Dniepr-Donets Basin [in Ukrainian]. Mineral Resources of Ukraine, 2003, 20-25.
Bábek, O., Kumpan, T., Kalvoda, J. and Grygar, T.M., 2016. Devonian/Carboniferous boundary glacioeustatic fluctuations in a platform-to-basin direction: A geochemical approach of sequence stratigraphy in pelagic settings. Sedimentary Geology, 337, 81-99.

Buggisch, W., 1991. The global Frasnian-Famennian "Kellwasser Event". Geologische Rundschau, 80, 49-72.

Calvert, S.E., Bustin, R.M. and Ingall, E.D., 1996. Influence of water column anoxia and sediment supply on the burial and preservation of organic carbon in marine shales. Geochimica et Cosmochimica Acta, 60, 1577-1593.

Dvorjanin, E.S., Samoilyuk, A.P., Egurnova, M.G., Zaykovsky, N.Y., Podladchikov, Y.Y., van den Belt, F.J.G. and de Boer, P.L., 1996. Sedimentary cycles and paleogeography of the Dnieper Donets Basin during the late Visean-Serpukhovian based on multiscale analysis of well logs. Tectonophysics, 268, 169-187.

Gradstein, F., Ogg, J. and Smith, A., 2004. A Geological Time Scale 2004. Cambridge University Press, Cambridge.

Ivanyuta, M.M., Fedyshyn, V.O., Denega, B.I., Arsiriy, Y.O. and Lazaruk, Y.G., 1998. Atlas of oil and gas fields of Ukraine. Six volumes. Ukrainian Oil and Gas Academy, Lviv.

Jarvie, D.M., Hill, R.J., Ruble, T.E. and Pollastro, R.M., 2007. Unconventional shale-gas systems: the Mississippian Barnett Shale of north-central Texas as one model for thermogenic shale-gas assessment. AAPG Bulletin, 91/4, 475-499.

JCPDS, 1974. Joint Committee for the Powder Diffraction Standards: Selected Powder Diffraction Data for Minerals. Pennsylvania, USA: JCPDS.

Jones, B. and Manning, D.A.C., 1994. Comparison of geochemical indices used for the interpretation of paleoredox conditions in ancient mudstones. Chemical Geology, 111, 111-129.

Kabyshev, B., Krivchenkov, B., Stovba, S. and Ziegler, P.A. 1998. Hydrocarbon habitat of the Dniepr-Donets Depression. Marine and Petroleum Geology, 15, 177-190.

Kabyshev, B.P., Kabyshev, Y.B., Krivosheev, V.T., Prigarina, T.M. and Ulmishek, G.F., 1999. Oil-gas-generating characteristics of Paleozoic rocks of the Dniepr-Donets Basin based on Rock-Eval pyrolysis [Russian]. Reports of the National Academy of Sciences of Ukraine, 12, 112-117.

Machulina, S.A. and Babko, I.M., 2004. On the geology of Visean Domanik-type rocks in the Dniepr-Donetsk Depression (in Ukrainian). Naft. i gasova prom-st., 5, 3-8.

Misch, D., Wegerer, E. and Scheucher, L., 2014. Clay-mineral composition of black shales from the Dniepr-Donets Basin (Ukraine). Abstract book of the $7^{\text {th }}$ Mid-European Clay Conference 2014, Dresden, Germany. 82 pp.

Misch, D., Sachsenhofer, R.F., Bechtel, A., Gratzer, R., Gross, D. and Makogon, V., 2015. Oil/gas-source rock correlations in the Dniepr-Donets Basin (Ukraine): New insights into the petroleum system. Marine and Petroleum Geology, 67, 720-742. https://doi.org/10.1016/j. marpetgeo.2015.07.002

Misch, D., Gross, D., Mahlstedt, N., Makogon, V. and Sachsenhofer, R.F., 2016a. Shale gas/shale oil potential of upper Visean Black Shales in the Dniepr-Donets Basin 
(Ukraine). Marine and Petroleum Geology, 75, 203-219. https://doi.org/10.1016/j.marpetgeo.2016.04.017

Misch, D., Mendez-Martin, F., Hawranek, G., Onuk, P., Gross, D. and Sachsenhofer, R.F., 2016b. SEM and FIB-SEM investigations on potential gas shales in the Dniepr-Donets Basin (Ukraine): pore space evolution in organic matter during thermal maturation. IOP Conference Series: Material Science and Engineering, 109, paper 012010. https://doi.org/10.1088/1757-899X/109/1/012010.

Misch, D., Klaver, J., Gross, D., Mayer-Kiener, V., Mendez-Martin, F., Schmatz, J. and Sachsenhofer, R.F., subm. Factors controlling shale microstructure and porosity: A case study from the Ukrainian Dniepr-Donets Basin. Submitted to AAPG Bulletin.

Mohsenian, E., 2013. Multidimensional Basin Modeling in the Central Persian Gulf basin (offshore Iran) and the Dniepr-Donets basin (Ukraine), PhD thesis Montanuniversitaet Leoben, 200 pp.

Niebuhr, B., 2005. Geochemistry and time-series analyses of orbitally forced Upper Cretaceous marl-limestone rhythmites (Lehrte West Syncline, northern Germany). Geological Magazine, 142, 31-55.

Rachold, V. and Brumsack, H.J., 2001. Inorganic geochemistry of Albian sediments from the Lower Saxony Basin, NW Germany: paleoenvironmental constraints and orbital cycles. Palaeogeography Palaeoclimatology Palaeoecology, 174, 121-143.

Ross, D.J.K. and Bustin, R.M., 2008. Characterizing the shale gas resource potential of Devonian-Mississippian strata in the Western Canadian Sedimentary Basin: application of an integrated formation evaluation. AAPG Bulletin, 92, 87-125. https://doi.org/10.1306/09040707048

Ross, D.J.K. and Bustin, R.M., 2009. Investigating the use of sedimentary geochemical proxies for paleoenvironment interpretation of thermally mature organic-rich strata: examples from the Devonian-Mississippian shales, Western Canadian Sedimentary Basin. Chemical Geology, 260, 1-19. https://doi.org/10.1016/j. chemgeo.2008.10.027

Sachsenhofer R.F., Privalov V.I., Izart A., Elie M., Kortensky J., Panova E.A., Sotirov A. and Zhykalyak, M.V., 2003. Petrography and geochemistry of Carboniferous coal seams in the Donets Basin (Ukraine): implications for paleoecology. International Journal of Coal Geology, 55, 225-259.

Sachsenhofer, R.F., Shymanovskyy, V.A., Bechtel, A., Gratzer, R., Horsfield, B. and Reischenbacher, D., 2010. Paleozoic Source Rocks in the Dniepr-Donets Basin (Ukraine). Petroleum Geoscience, 16, 377-399. https:// doi.org/10.1144/1354-079309-032

Sachsenhofer R.F., Privalov, V.A. and Panova, E.A., 2012. Basin evolution and coal geology of the Donets Basin (Ukraine, Russia): An overview. International Journal of Coal Geology, 89, 26-40. https://doi.org/10.1016/j. coal.2011.05.002

Sachsenhofer, R.F., Hentschke, J., Bechtel, A., Coric, S., Gratzer, R., Gross, D., Horsfield, B., Rachetti, A. and Soliman, A., 2015. Hydrocarbon potential and depositional environments of Oligo-Miocene rocks in the Eastern Carpathians (Vrancea Nappe, Romania). Marine and Petroleum Geology, 68, 269-290. https://doi.org/10.1016/j. marpetgeo.2015.08.034

Schultz, L.G., 1964. Quantitative interpretation of mineralogical composition from X-ray and chemical data for the Pierre shale. US Geological Survey Professional Paper, 391-C, 1-31.

Shchipansky, A. and Bogdanova, S.V., 1996. The Sarmatian crustal segment: Precambrian correlation between the Voronezh Massif and the Ukrainian Shield across the Dniepr-Donets Aulacogen. Tectonophysics, 268, 109-125. Shymanovskyy, V.A., Sachsenhofer, R.F., Izart, A. and Li, Y., 2004. Modelling of the thermal evolution of the northwestern Dniepr-Donets Basin (Ukraine). Tectonophysics 381, 61-79.

Tukey, J. W., 1977. Exploratory Data Analysis. AddisonWesley Publishing Company, 688 pp.

Ulmishek, G.F., 2001. Petroleum geology and resources of the Dnieper-Donets Basin, Ukraine and Russia. US Geological Survey Bulletin 2201-E, http://geology.cr.usgs. gov/pub/bulletins/b2201-e/.

Ulmishek, G.F., Bogino, V.A., Keller, M.B. and Poznyakevich, Z.L., 1994. Structure, stratigraphy, and petroleum geology of the Pripyat and Dnieper-Donets basins, Byelarus and Ukraine. In: Landon, S.M. (ed.) Interior Rift Basins. AAPG Memoir, 59, 125-156.

Yarincik, K.M., Murray, R.W. and Peterson, L., 2000. Climatically sensitive eolian and hemipelagic deposition in the Cariaco Basin, Venezuela, over the past 578,000 years: results from $\mathrm{Al} / \mathrm{Ti}$ and $\mathrm{K} / \mathrm{Al}$. Paleoceanography, 15, 210-228.

Received: 13102017

Accepted: 09022018

David MISCH ${ }^{1)^{*}}$, Eva WEGERER ${ }^{1)}$, Doris GROSS ${ }^{1)}$, Reinhard F. SACHSENHOFER ${ }^{1)}$, Alessandra RACHETTI ${ }^{2)}$ \& Reinhard GRATZER ${ }^{1)}$

1) Department of Applied Geosciences and Geophysics, Montanuniversitaet Leoben, Peter-Tunner-Straße 5, 8700 Leoben, Austria;

2) Department of General, Analytical and Physical Chemistry, Montanuniversitaet Leoben, Franz-Josef-Straße 18, 8700 Leoben, Austria;

*) Corresponding Author: David.Misch@unileoben.ac.at 